\title{
Calculating the optimal physical size of an industrial plate recuperator
}

\author{
Vitalii M. Tauger ${ }^{1 *}$, Ivan V. Minin ${ }^{1}$, Vitalii E. Adas ${ }^{1}$ \\ 1 Ural State Mining University, Ekaterinburg, Russia \\ *e-mail: tauger2016@yandex.ru
}

\begin{abstract}
Introduction. The wide spread of plate heat exchangers in various fields of technology is due to the simplicity of their design and a variety of layout schemes. An area where their use is very promising is heat recovery. The effect of an air heat exchanger-recuperator consists in heating the incoming flow with the heat of the outgoing flow and is expressed in drastically reduced power consumption, which would otherwise be spent on heating.

Research methodology. The object of research is a recuperator designed to heat the air entering the production room in winter. Resistance to air flow is a significant disadvantage of the plate heat exchange. The aerodynamic resistance reduces the flow rate, therefore, leads to a decrease in the flow rate of air passing through the recuperator, so the required flow rate is ensured by special fan installations. The task of designing a recuperator is to minimize the size of the flow part and prevent excessive load on the fan unit. Calculation with the use of the recuperatorTs mathematical model is applied in the research. Results. In the course of the research, a mathematical model of the recuperator has been developed, which includes a condition for limiting the pressure loss by an acceptable value. Ratios have been obtained for determining the optimal duct width between the plates, plates height, length and number. Conclusion. A simplified mathematical model has been proposed to estimate the dimensions of the flow part. The reliability of the simplified model has been confirmed by numerical calculation.
\end{abstract}

Key words: plate heat exchanger; recuperator; aerodynamic drag; ventilation; flow; flow part; duct.

Introduction. Heat exchangers of various types including the plate ones are widely applied in technical equipment in order to ensure the temperature specifications for equipment operation and comfortable working conditions for the staff [1-4]. Plate heat exchanger's operation is based on the transfer of heat energy from one fluid (heat carrier) to another through the separating wall, i. e. plate. The scheme of the cocurrent heat exchanger is shown at fig. 1 .

The body 1 contains the heat-transmitting plates 2 which make up a line of ducts. Along the duct $\delta_{h}$ wide travels the heat carrier (denoted by red arrows at the duct's inlet), while along the duct $\delta_{c}$ wide travels the heated (cold) medium (denoted by blue arrows at the duct's inlet). The ducts with the heat carrier and cold medium alternate. Media travel round the ducts is accompanied by heat transfer from the heat carrier to the cold medium through the separating plate. The heat carrier gets cooler (denoted by blue arrows at the duct's outlet), while the cold flow gets heated (denoted by red arrows at the duct's outlet).

Plate heat exchangers are widely used both in engineering and private life due to their simple design. Heat recuperation is an area where their application seems promising enough [5-8]. The effect of an air heat exchanger-recuperator consists in heating the incoming flow with the heat of the outgoing flow and is expressed in drastically reduced power consumption, which would otherwise be spent on heating. The recuperator is studied later in the research which is aimed at heating the incoming 
air in winter period when its low temperature may cause equipment overcooling and break comfortable working conditions.

Along with advantages such as the mentioned simplicity of the design and the possibility of implementing various structural solutions (cocurrent, countercurrent and crossflow schemes), the plate recuperator also has a significant drawback, which is its resistance to flow of medium inside the ducts. Aerodynamic resistance reduces the flow velocity, resulting in the reduced consumption of air passing through the recuperator. So the required flow rate is ensured by special fan installations. Industrial recuperators are aimed at rather high flow rates. For instance, air recuperators for workshops are designed for the flow rate of $10-100 \mathrm{~m}^{3} / \mathrm{s}$. In order to operate, such a device requires a large cross-section or/and a large number of ducts as well as relatively high differential pressure, therefore, high fan power consumption. That is why the designer often has to solve the problem of optimization and compromise, i. e. deliberately set too high capacity and size of the ventilation installation in return of the recuperator size minimization.

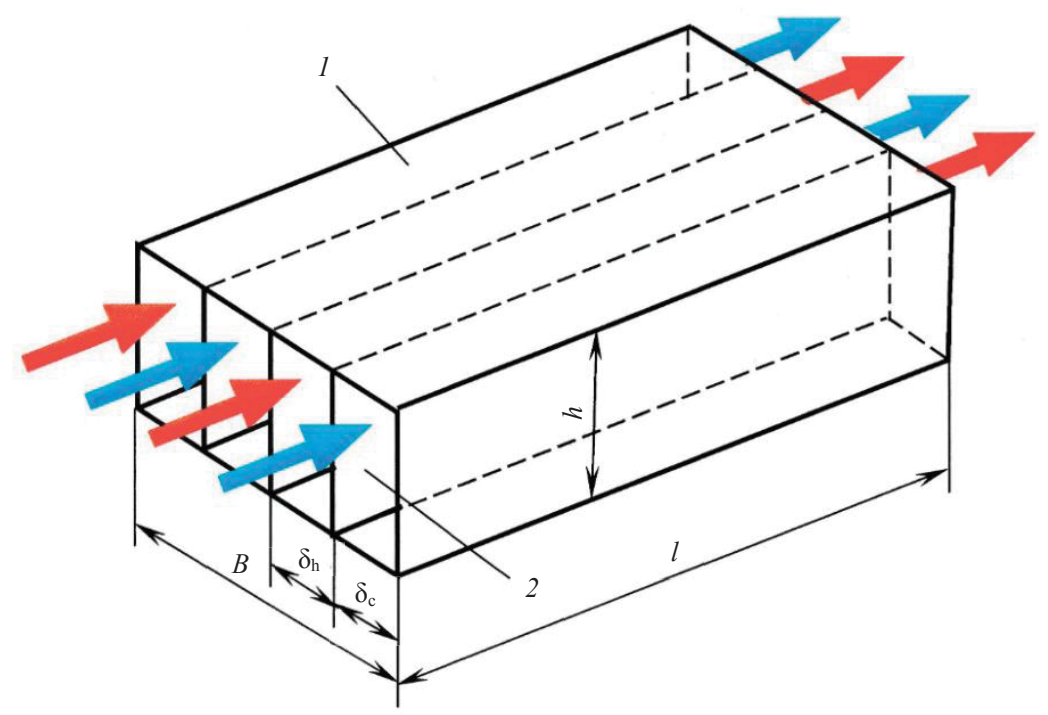

Fig. 1. The scheme of the concurrent heat exchanger

Рис. 1. Схема пластинчатого прямоточного теплообменника

Research methodology. Research aim is to obtain the ratios to determine the optimal width of the duct between the plates $\delta$, height $h$ and length $l$ of a plate. The following are the criteria of optimality:

- small size of the recuperator;

- maximum acceptable size of ducts' aerodynamic resistance.

The occupied volume, as a product of the overall dimensions of the recuperator's active part, is considered to be the indicator of the small size. The sizes of the ducts are calculated by the admissibility limit of the aerodynamic resistance:

$$
\begin{aligned}
& \Delta p_{h}=[\Delta p] ; \\
& \Delta p_{c}=[\Delta p],
\end{aligned}
$$

where $\Delta p_{h}, \Delta p_{c}$ is the depression of the ducts with heated and cold flows correspondingly; $[\Delta p]$ the maximum admissible depression. 
Recuperator's mathematical model is constructed taking into account that the area of the heat transferring surface $F$ has been obtained earlier with the help of the assumptions of thermodynamics and thermal engineering $[9,10]$.

Research results. By the dimensions of the plates and the distances between them, both the dimensions and the aerodynamic resistance of the recuperator are determined. Thus, these parameters are interconnected.

Let us consider the typical instance, where the mass flow rates the incoming and the outgoing flows are equal.

The equality of the mass flow rates is realized:

$$
Q_{h 1} \rho_{h 1}=Q_{c 1} \rho_{c 1},
$$

where $Q_{h 1}$ and $\rho_{h 1}$ are the volumetric rate and the density of the heat carrier at the inlet of the recuperator; $Q_{c 1}$ and $\rho_{c 1}$ are the volumetric rate and the density of the cold flow at the inlet of the recuperator.

Aerodynamic analysis is complicated by the fact that flow parameters change as soon as they pass through the ducts. The temperature of the heat carrier gets lower and its density grows. Consequently, the volumetric rate and velocity decrease. The temperature of the cold flow, on the contrary, gets higher being accompanied by the increase in the volumetric rate and velocity. However, taking into account the approximate character usual to aerodynamic analysis, it is reasonable to come to mean values of the parameters.

Then, air pressure drop at its passing through the ducts (without local resistances) will be expressed as follows $[11,12]$ :

$$
\begin{aligned}
& \Delta p_{h}=\lambda_{h} \frac{l}{d_{h}} \rho_{h} \frac{v_{h}^{2}}{2} ; \\
& \Delta p_{c}=\lambda_{c} \frac{l}{d_{c}} \rho_{c} \frac{v_{c}^{2}}{2},
\end{aligned}
$$

where $\lambda_{h}$ and $\lambda_{c}$ are the coefficients of aerodynamic (linear) resistance of ducts for heated and cold flows correspondingly; $\rho_{h}$ and $\rho_{c}$ are the mean densities of heated and cold air correspondingly; $v_{h}$ and $v_{c}$ are the mean velocities of heated and cold flows correspondingly; $d_{h}$ and $d_{c}$ are the typical sizes (hydraulic diameter) of ducts for heated and cold flows correspondingly.

In case when $\delta_{h}\left(\delta_{c}\right)<<h$, the hydraulic diameters are $d_{h}=2 \delta_{h} ; d_{c}=2 \delta_{c}$.

Considering that the flow of one direction travels along a half of the total number of ducts $z$, and applying ratios

$$
\begin{gathered}
Q_{h 1} \rho_{h 1}=Q_{h} \rho_{h}=Q_{c} \rho_{c} ; \\
v_{h}=\frac{2 Q_{h}}{z \delta_{h} h} ; \\
v_{c}=\frac{2 Q_{c}}{z \delta_{c} h},
\end{gathered}
$$

we get:

$$
v_{c}=\frac{2 Q_{h} \rho_{h}}{\rho_{c} z \delta_{c} h} .
$$


Flow velocity in the duct of an industrial recuperator, as a rule, is not less than $10 \mathrm{~m} / \mathrm{s}$. Estimated calculations have shown that the most probable is the pre-quadratic flow regime where coefficients $\lambda_{h}$ and $\lambda_{c}$ (expressions (3)) are to be calculated by the Altshuler formula $[13,14]$ :

$$
\begin{aligned}
& \lambda_{h}=0,11\left(\frac{68}{\operatorname{Re}_{h}}+\frac{\Delta_{e}}{d_{h}}\right)^{0,25} ; \\
& \lambda_{c}=0,11\left(\frac{68}{\operatorname{Re}_{c}}+\frac{\Delta_{e}}{d_{c}}\right)^{0,25},
\end{aligned}
$$

where $\mathrm{Re}_{h}$ and $\mathrm{Re}_{c}$ are the Reynolds numbers characterizing the flow inside the ducts with heated and cold flows; $\Delta_{e}$ is the equivalent roughness of plates surface.

The Reynolds numbers for the heat carrier and the cold flow averaged in temperature ranges are

$$
\begin{aligned}
& \operatorname{Re}_{h}=\frac{v_{h} d_{h}}{v_{h}} ; \\
& \operatorname{Re}_{c}=\frac{v_{c} d_{c}}{v_{c}},
\end{aligned}
$$

where $v_{h}$ and $v_{c}$ are the mean coefficients of kinematic viscosity of the flows in the corresponding temperature intervals.

Despite the apparent difference between $\mathrm{Re}_{h}$ and $\mathrm{Re}_{c}$ as far as the size is concerned, the value of $\lambda_{h}$ is little different from $\lambda_{c}$, then $\lambda_{h} \approx \lambda_{c}$.

For an extreme case of $\Delta p_{h}=\Delta p_{c}=[\Delta p]$ expressions (3) with the account of expression (5) are transformed into the following:

$$
\lambda_{h} \frac{l}{\delta_{h}^{3}} \rho_{h}\left(\frac{Q_{h}}{z h}\right)^{2}=\lambda_{c} \frac{l}{\delta_{c}^{3} \rho_{c}}\left(\frac{Q_{h} \rho_{h}}{z h}\right)^{2}=[\Delta p] .
$$

Equation (8) informs of the ducts' width

$$
\delta_{c}=\sqrt[3]{\frac{\rho_{h}}{\rho_{c}}} \delta_{h}
$$

making it possible to estimate whether it is significant to construct the ducts of different width to reduce the size $B$ of the recuperator.

Rough estimates by the probable values of mean density in temperature ranges of flows show that the difference of the ducts' width does not exceed $0.05 \delta_{h}$. In small-size industrial recuperators the width of the duct has the period of $10 \mathrm{~mm}$, so the construction of ducts with such a difference is not only irrational, but often just technologically impossible. So, it is possible to accept $\delta_{h}=\delta_{c}=\delta$, which allows calculating by a duct, for instance by the heat carrier. Total area of plates must be equal to $F$, so

$$
F=(z-1) h l .
$$


Equations (1)-(10) represent a full mathematical model of an optimal recuperator. After reduction it is reduced to the system of equations (10):

$$
\left\{\begin{array}{l}
\lambda_{h} \frac{l}{\delta^{3}} \rho_{h}\left(\frac{Q_{h}}{z h}\right)^{2}=[\Delta p], \\
(z-1) h l=F .
\end{array}\right.
$$

System (10) contains five unknown quantities: $\delta, h, l, z, \Delta_{e}$, so basically, it can be solved only after the well-grounded substantiation of three independent parameters [15]. However, in this case the solution is going to be labor-intensive, particularly due to the unknown quantities in $\lambda_{h}$ coefficient. For rough estimation it is reasonable to use a feature of the coefficient $\lambda_{h}$, which is poor dependence of its value on the variation of $\operatorname{Re}_{h}$ and $d_{h}$ in formula (6). As applied to wide ranges of velocity and temperature, the sufficient reliability of calculation will be ensured if $\lambda_{h}=0.035$.

Let us illustrate the procedure of rough estimation by an example. Industrial recuperator with consumption $Q_{h}=100 \mathrm{~m}^{3} / \mathrm{s}$ is designed to heat the air coming into the workshop in winter period by the heat of the outgoing flow. As a result of the thermodynamic calculation the value of $F=3800 \mathrm{~m}^{2}$ has been obtained. Mean density of the outgoing air is $\rho_{h}=1.23 \mathrm{~kg} / \mathrm{m}^{3}$ for the average temperature of $14{ }^{\circ} \mathrm{C}$. Ventilation system is designed for the admissible pressure difference in the flow part of the recuperator $[\Delta p]=300 \mathrm{~Pa}$. Let us find the size of the flow part.

The accepted parameters: $\lambda_{h}=0.035 ; \delta=0.016 \mathrm{~m} ; h=2.5 \mathrm{~m}$.

In order to simplify, it is considered that $(z-1) \approx z$. Then it follows from the first equation of the system that

$$
z=\frac{1}{\delta h} \sqrt[3]{\frac{\lambda_{h} F \rho_{h} Q_{h}^{2}}{[\Delta p]}},
$$

and from the second equation

$$
l=\frac{F}{(z-1) h} .
$$

The substitution of numerical values into formulae (11), (12) makes it possible to obtain $z=440$ and $l=3.5 \mathrm{~m}$. So, the dimensions of the recuperator's flow part (without plates' width) are $l \times B \times h=3.5 \times 7.0 \times 2.5 \mathrm{~m}$, and its volume is $V=61.25 \mathrm{~m}^{3}$.

Results analysis. Average velocity of the heat carrier in the ducts calculated by the corresponding formula (4), $v_{h}=11.4 \mathrm{~m} / \mathrm{s}$. The Reynolds number (formula (7)) for the obtained value of velocity and the accepted width of the duct is $\operatorname{Re}_{h}=24300$, the coefficient of the aerodynamic resistance of a duct (formula (6)) $\lambda_{h}=0.031$, duct's resistance (formula (3)) $\Delta p=271 \mathrm{~Pa}<[\Delta p]=300 \mathrm{~Pa}$, the error conditioned by the assumptions made up minus $9.7 \%$ from $[\Delta p]$, which is quite satisfactory for aerodynamic calculations.

Conclusion. The mathematical model of the plate recuperator based on the condition of limiting the aerodynamic resistance by the admissible value, makes it possible to minimize the dimensions and volume of the recuperator's active part. A simplified mathematical model has been proposed, the reliability of which has been confirmed by numerical calculation. 


\section{REFERENCES}

1. Prokhorov V. B., Denishchuk D. A. Use of condensing heat exchangers for deep heat recovery of coal and oil-fired boiler's exhaust gases. Teplovye protsessy $v$ tekhnike $=$ Thermal Processes in Engineering. 2017; 8 (T. 9): 377-382. (In Russ.)

2. Pechenegov Iu. Ia. A reverse-flow plate heat exchanger with optimal parameters for ventilation systems. Energobezopasnost $i$ energosberezhenie = Energy Safety And Energy Economy. 2019; 2: 29-33. (In Russ.)

3. Jeong K., Kessen M., Bilirgen H., Levy E. Analytical modeling of water condensation in condensing heat exchanger. International Journal of Heat and Mass Transfer. 2010; 53: 2361-2368.

4. Shi X., Che D., Agnew B., Gao J. An investigation of the performance of compact heat exchanger for latent heat recovery from exhaust flue gases. International Journal of Heat and Mass Transfer. 2011; 54: 606-615.

5. Akhmiarov T. A., Beliaev V. S., Spiridonov A. V., Shubin I. L. The system of active energy conservation with heat recuperation. Energosberezhenie = Energy Conservation Journal. 2013; 4: 36-46. (In Russ.)

6. Godo M., Takatsuka T., Shindo S. Study on energy saving air-conditioning compact desiccant ventilation units. In: International Symposium on Next-generation Air Conditioning and Refrigeration Technology. 2010: 6.

7. Godo M. Study on energy saving air-conditioning system using compact desiccant ventilation units. Comparison of Regeneration Efficiency. In: JSRAE Annual Conf. 2008. P. 125-128.

8. Godo M. Study on energy saving air-conditioning system using compact desiccant ventilation units. Adsorption and desorption behavior of the direct heating regeneration type. In: JSRAE Annual Conf. 2009. P. 427-430.

9. Golovanchikov A. B., Prokhorenko N. A., Merentsov N. A., Smolskaia D. O., Ostapenko A. A. Modeling of heat processes under the flashing motion of the hot and cold heat carrier in the double-sheed coil heat exchanger. Energo- $i$ resursosberezhenie: promyshlennost $i$ transport $=$ Energy and Resource Saving: Industry and Transport. 2019; 1: 7-10.

10. Boltenko E. A. The efficiency of heat transfer in heat-transfer apparatuses with interacting swirled and transit flows. Teploenergetika = Thermal Engineering. 2019; 1: 85-90. (In Russ.)

11. Kovalevskii V. F. Heat-exchanging devices and thermal analyses of mining machinery hydraulic actuator. Moscow: Nedra Publilshing; 1972. (In Russ.)

12. Khorin V. N. Hydrostatic power drive of downhole equipment. Moscow: Nedra Publilshing; 1980. (In Russ.)

13. Morozova N. V., Korshak A. A. Pipeline hydraulic calculations and border Reynolds numbers. Neftegazovoe delo = Oil and Gas Business. 2007; 1 (T. 5): 120-125. (In Russ.)

14. PKF Spetsdetal. Separate hydraulic design of pipeline. Available from: https://pkfdetal.ru/info/15samostoyatelnyj-gidravlicheskij-raschet-truboprovoda [Accessed $15 \mathrm{May}, 2020$ ].

15. Salimov R. B. Mathematics for engineers and industrial engineers. Moscow: FIZMATLIT Publishing; 2009. (In Russ.)

Received 21 May 2020

\section{Information about authors:}

Vitalii M. Tauger - PhD (Engineering), Associate Professor, Head of Engineering Mechanics Department, Ural State Mining University. E-mail: tauger2016@yandex.ru

Ivan V. Minin - researcher, Department of Commercial Research, Ural State Mining University. E-mail: mr.minin-ivan@yandex.ru

Vitalii E. Adas - laboratory assistant, Department of Mining Machinery Operations, Ural State Mining University. E-mail: vintus66@mail.ru5

\section{Расчет оптимальных размеров пластинчатого рекуператора промышленного назначения}

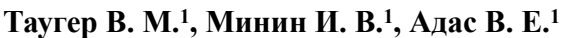

1 Уральский государственный горный университет, Екатеринбург, Россия.

\section{Peфepam}

Введение. Широкое распространение пластинчатых теплообменников в различных областях техники объясняется простотой их конструкиии и разнообразием компоновочных схем. Одна из областей, в которой их использование представляется весьма перспективным, - рекуперация тепла. Эффект воздушного теплообменника-рекуператора состоит в нагреве входящего потока теплом исходящего потока и выражается в резком снижении расхода электроэнергии, которая в противном случае затрачивалась бы на нагрев.

Методика проведения исследования. Объектом исследования является рекуператор, предназначенный для нагрева воздуха, входящего в производственное помещение, в зимний период. Существенный недостаток пластинчатого рекуператора состоит в сопротивлении течению воздуха. Аэродинамическое сопротивление снижает скорость потока, следовательно, приводит к уменьшению расхода проходящего через рекуператор воздуха, поэтому потребный расход обеспечивается специиальными вентиляторными установками. Задачей проектирования 
рекуператора является минимизация размеров проточной части с предотвращением сверхнормативной нагрузки на вентиляторную установку. В исследовании применены расчеть с использованием математической модели рекуператора.

Результаты исследования. В ходе исследования составлена математическая модель рекуператора, включающая в себя условие ограничения потери давления допускаемой величиной. Получены соотношения для определения оптимальных ширины канала между пластинами, высоты и длины пластины, а также числа пластин.

Вывод. Предложена упрощенная математическая модель, позволяющая оценить габариты проточной части. Достоверность упрощенной модели подтверждена числовым расчетом.

Ключевые слова: пластинчатый теплообменник; рекуператор; аэродинамическое сопротивление; вентилячия; поток; проточная часть; канал.

\section{БИБЛИОГРАФИЧЕСКИЙ СПИСОК}

1. Прохоров В. Б., Денищук Д. А. Использование теплообменников конденсационного типа для глубокой утилизации теплоты дымовых газов при сжигании твердого и жидкого топлива // Тепловые процессы в технике. 2017. № 8 (Т. 9). С. 377-382.

2. Печенегов Ю. Я. Пластинчатый теплоутилизатор с реверсивным движением потоков теплоносителей и оптимальными параметрами для вентиляционных систем // Энергобезопасность и энергосбережение. 2019. № 2. С. 29-33.

3. Jeong K., Kessen M., Bilirgen H., Levy E. Analytical modeling of water condensation in condensing heat exchanger // International Journal of Heat and Mass Transfer. 2010. No. 53. P. 2361-2368.

4. Shi X., Che D., Agnew B., Gao J. An investigation of the performance of compact heat exchanger for latent heat recovery from exhaust flue gases // International Journal of Heat and Mass Transfer. 2011. No. 54. P. 606-615.

5. Ахмяров Т. А., Беляев В. С., Спиридонов А. В., Шубин И. Л. Система активного энергосбережения с рекуперацией тепла // Энергосбережение. 2013. № 4. С. 36-46.

6. Godo M., Takatsuka T., Shindo S. Study on energy saving air-conditioning compact desiccant ventilation units // International Symposium on Next-generation Air Conditioning and Refrigeration Technology. 2010. P. 6.

7. Godo M. Study on energy saving air-conditioning system using compact desiccant ventilation units. Comparison of Regeneration Efficiency // JSRAE Annual Conf. 2008. P. 125-128.

8. Godo M. Study on energy saving air-conditioning system using compact desiccant ventilation units. Adsorption and desorption behavior of the direct heating regeneration type // JSRAE Annual Conf. 2009. P. 427-430.

9. Голованчиков А. Б., Прохоренко Н. А., Меренцов Н. А., Смольская Д. О., Остапенко А. А. Моделирование тепловых процессов при противоточном движении горячего и холодного теплоносителя в двухходовом кожухотрубном теплообменнике // Энерго- и ресурсосбережение: промышленность и транспорт. 2019. № 1. С. 7-10.

10. Болтенко Э. А. Эффективность теплообмена в теплопередающих устройствах с использованием взаимодействующих закрученного и транзитного потоков // Теплоэнергетика. 2019. № 1. С. 85-90.

11. Ковалевский В. Ф. Теплообменные устройства и тепловые расчеты гидропривода горных машин. М.: Недра, 1972. 224 с.

12. Хорин В. Н. Объемный гидропривод забойного оборудования. М.: Недра, 1980. 415 с.

13. Морозова Н. В., Коршак А. А. О границах зон трения при гидравлическом расчете нефте- и нефтепродуктопроводов //Нефтегазовое дело. 2007. № 1 (Т. 5). С. 120-125.

14. Самостоятельный гидравлический расчет трубопровода URL: https:/pkfdetal.ru/info/15samostoyatelnyj-gidravlicheskij-raschet-truboprovoda (дата обращения: 15.05.2020).

15. Салимов Р. Б. Математика для инженеров и технологов. М.: ФИЗМАТЛИТ, 2009. 484 с.

Поступила в редакцию 21 мая 2020 года

\section{Сведения об авторах:}

Таугер Виталий Михайлович - кандидат технических наук, доцент, заведующий кафедрой технической механики Уральского государственного горного университета. E-mail: tauger2016@yandex.ru

Минин Иван Вадимович - инженер-исследователь отдела хоздоговорных научноисследовательских работ Уральского государственного горного университета. E-mail: mr.minin-ivan@yandex.ru

Адас Виталий Евгеньевич - лаборант кафедры эксплуатации горного оборудования Уральского государственного горного университета. E-mail: vintus66@mail.ru

Для цитирования: Таугер В. М., Минин И. В., Адас В. Е. Расчет оптимальных размеров пластинчатого рекуператора промышленного назначения // Известия вузов. Горный журнал. 2020. № 6. C. 95-101 (In Eng.). DOI: 10.21440/0536-1028-2020-6-95-101

For citation: Tauger V. M., Minin I. V., Adas V. E. Calculating the optimal physical size of an industrial plate recuperator. Izvestiya vysshikh uchebnykh zavedenii. Gornyi zhurnal $=$ News of the Higher Institutions. Mining Journal. 2020; 6: 95-101. DOI: 10.21440/0536-1028-2020-6-95-101 